\title{
BY DISOBEDIENCE TO SUCCESS: WHEN BRAND VALUE SHOULD BE MEASURED IN A DIFFERENT WAY THAN HOW THE THEORY RECOMMENDS
}

\author{
Jana Kliestikova ${ }^{1}$, Maria Kovacova ${ }^{2}$ \\ ${ }^{I}$ University of Zilina, Faculty of Operation and Economics of Transport and Communications, Slovak Republic, \\ jana.kliestikova@fpedas.uniza.sk \\ ${ }^{2}$ University of Zilina, Faculty of Operation and Economics of Transport and Communications, Slovak Republic, \\ maria.kovacova@fpedas.uniza.sk
}

\begin{abstract}
Brand value building and managing is an interdisciplinary issue with serious impact on company's effective market performance. Knowing this, more and more companies try to extract the competitive advantage of a valuable brand. But there are a lot of practical restrictions that result from universal application of formulated theory without respecting national specifics and which often lead to company's activities in scope of branding and brand value measuring not being successful. This is the reason for scepticism towards the implementation of brand management activities, especially in former socialistic countries where the tradition of brand is not so developed due to the long-term application of principles of planned economy. So, the undesirable spiral mechanism is evident - domestic companies apply inconvenient methods of branding and brand value evaluation - brand value decreases - companies rather do not build and manage theirs brands - brands lose their competitive potential in comparison with foreign competitors and the market deforms -only strong foreign brands applying their national branding mechanisms survive - the impression of the so called 'good practice' is created - the domestic companies apply inconvenient methods of branding and the circle starts again. According to this, the aim of this paper is to critically discuss the applicability of selected brand valuation methods in the specific conditions of Slovak republic and to verify its applicability in the context of framework conditions of their applicability. To achieve this aim, after the application of selected criteria, we applied the following methods of brand value measurement: royalty savings and brand value added.
\end{abstract}

Keywords: brand; brand value; brand valuation.

JEL Classification: M21, M31, M40.

\section{Introduction}

Accelerating trend of globalization is now an essential attribute that affects the saturation of competitive environment of each sub-market. So, the attention of managers is focused on the increase of emphasis on effective building of a competitive advantage that will provide companies with the required consumer preferences conditional for the fulfilment of specified aims of a company. Concerning the increase of brand importance as a selected tool of a company marketing mix, not only in an international environment but also in domestic market, the activation of marketing activities of the business entity in the field of building value of this marketing mix tool seems to be a promising way to build a solid competitive advantage.

However, taking into account the historical development of traditions of targeting, positioning and building of brand value in the Slovak Republic, it can be stated, that, despite the prolonged exposure of market economy mechanisms, the experiences of domestic enterprises in marketing activities in the field of brand are deficient. Based on the growing need for implementation of an effective system for building of brand value as a selected marketing mix tool with important competitive potential, thus creates a space for the development of relevant brand value metrics with a positive impact on decisionmaking processes of marketing managers in the field of building the brand value in domestic enterprises. In order to tackle the existing deficient situation of the solution of this issue and out of the need for creation of integrated model of building of a brand value, it is extremely important to also 
consider the impacts of global economic crisis, that has undermined the previously stable market positions of many enterprises.

Due to this fact, it has created not only a market gap and related new business opportunities, but also an opportunity for the modification of previously applied marketing concepts, whose weaknesses and problematic aspects were revealed by an exposure to the economic crisis of global proportions. Brand problem has become one of those concepts that opens new perspectives for further development, not only at the level of brand building by uprising companies that fill up a created market gaps, but also at the level of brand management in those enterprises that have managed, despite the crisis, to stay in the marketplace. Just emphasized timeliness of creation of comprehensive methodology usable in domestic enterprises that builds a brand value, as a prospective source of stable competitive advantage, is the primary impulse to critically discuss the applicability of the selected brand valuation methods in the specific conditions of Slovak republic and to verify its applicability in the context of framework conditions of their applicability.

To do this, we used the standard scientific methods applied in the context of the provided case study of the selected Slovak company and its brand value measurement using the recommended metrics and detecting convergences and divergences between them and the obtained results. Based on the application of the selected criteria (theoretic concepts and recommendations, access to the data, common practice of Slovak companies and character of the method), we applied these methods of brand value measurement: royalty savings and brand value added (BVA ${ }^{\mathrm{TM}}$ method).

\section{Literature Review}

Past experience shows that the implementation of marketing concepts without adequate consideration of the specificities of the environment does not lead to the achievement of the set objectives; on the contrary, many times the market position of the company weakens as a consequence of such an action. These conclusions are based mainly on the studies realized by Beleska-Spasova et al. (2016) and Heine and Gutsatz (2015), who have consistently identified significant convergences between the predicted and realistically achieved impacts of marketing activities implemented in a general version. It has been detected, that the main reason of this situation was that the theoretical concepts were applied without regard to the specifics of the brand environment. Sydoruk (2016), Lizbetinova and Weberova (2016), Weberova and Lizbetinova (2016) and Starchon et al. (2016) developed this theory and focused their research on the specifics of brand management activities across marketing tools and sectoral belonging. But there appropriate attention has not been paid to the need of modification of brand value measurement approaches in the scope of environmental specifics. So, it is vital to find convergences and divergences in these methods and the results obtained by their implementation if the brand should be managed effectively.

The models for brand value measurement can be divided into financial, behavioural and crosssectional. Financially oriented approaches can be categorized as static and dynamic, which are then, in both cases, internally differentiated on the basis of cost, market and income orientation. (Salinas 2009). From the chronological point of view, the most used financial models are income oriented, especially Kern' model in 1962 (Zimmermann et al. 2001), Herp's model in 1982 (Herp 1982), Damodaran's model in 1994 (Damodaran 1996), Sander's model in 1995 (Raboy, Wiggins 1997), Feltham-Ohlson's model in 1996 (Feltham, Ohlson 1999), model of Sattler in 1997 (Sattler et al. 2002), Leo's model in 1999 (Lev 1999), Hirose's model in 2002 (Beccaceci et al. 2006), Fisher's model in 2007 (Fischer 2007), and so on. We can identify these metrics as traditional and these are subsequently replaced or eventually modified according to the evolution of specific needs of practice.

So, in addition to the financially-oriented models, there are the behaviourally oriented models that fulfil the need for building and managing the brand value evolved. The best known among these models are the model of brand barometer (Zimmermann et al. 2001), Vazquez's model (Vazquez et al. 2002), McKinsley's model (Riesenbeck 2000) or so called CBBE model (Keller 2007). Emnid/Horizont Brand Barometer is a model based on the scale assessment of individual universal predefined parameters of brand by consumers (Zimmermann et al. 2001). Vázquez et al. (2002) based their model on a combination of rewards of the product and the brand within the categorization of 
symbolic and functional benefits, while they quantify the brand value, within the mentioned, in the context of these basal categories: functional benefit associated with the product, symbolic benefit associated with the product, functional benefit associated with the brand and symbolic benefit associated with the brand. Although this model worked out in detail the perceived benefits to customers arising from the use of the brand, but the brand value concentrates only on the mentioned categories and like the previous model, it does not take into account its other possible determinants. McKinsley's model is based on the analysis of three key attributes of the brand, and hence its performance, personality and the perception of the consumer. These attributes are considered to be absolutely quantifiable (Riesenbeck 2000). The basic premise of the latest behavioural model for brand valuation, model CBBE, is that the real power of the brand corresponding with its value lies in what customers know about the brand, what they have indirectly heard about it and the type of relationship they have had with it during their long experiences. The brand value based on the customer's perspective, in the context of this model, according to Keller (2007), is methodologically defined as a differential effect that knowledge of the brand has on consumer response to marketing of the brand.

Not even this approach for the quantification of brand value has been suitable for the need of practice. But in contrast to the evolutional progress between the financial and behavioural approaches, when cross-sectional is discussed, first of all, the deficiencies have appeared simultaneously with the creation and development of behavioural approach. Then, the dominant idea for the measurement of the brand value has become a need to use the full strength of research techniques and processes that capture the greatest possible richness and complexity of the brand value (Keller 2007).

Similarly, according to Moisescu (2007), the reason for such an evolution was the necessity of implementation of the cross-sectional financial-behavioural approach to the determination of the brand value a prerequisite for obtaining reliable and valid data forming a platform for quality management decisions and full excerpted competitive potential, which optimally built and managed brand features. Representative of cross-sectional approach to analysis of brand value is a model presented by D. A. Aaker (2003), based on the assumption that the value of the brand is a set of assets and liabilities connected to the name and symbol of the brand, which increase or decrease the value of the product or service deliver to the enterprise or consumer, while the main categories of this value are the knowledge of the brand's name, brand loyalty, perceived quality and associations connected with the brand.

A similar approach to the analysed issue poses the majority of the world's market research agencies, while synthesizing the financial and consumer-oriented approaches to brand valuation, they use the socalled Multi Scoring Model, which combines both approaches. The total value of the brand is expressed on the basis of its financial value and in the alternatively quantified marketing factors. So, the dominant idea for the measurement of the brand value has become a need to use the full strength of research techniques and processes that capture the greatest possible richness and complexity of the brand value (Keller 2007). But the existing methods for the quantification of the brand value are still lacking in the approach that would take into account the specificities of the brand environment. The transition from universally designed postulates to generically categorization approach to brands is being increasingly referred to as an imperative to maximize their competitive potential.

The need for implementation of a differentiated approach to tackle the issue of building and managing the brand value was pointed out also by Moisescu (2007), Kapferer (2012) and Veloutsou and Guzman (2017). Krizanova et al. (2014) and Chailan and Ille (2015) also mentioned Moisescu (2007) in the case studies and partial questionnaire surveys through which they detected the sectoral and national characteristics of brand management in the automotive and fishing industry.

In the current market conditions of the Slovak Republic, the issue is the quantification of brand value and detection of its resources mainly analysed by Stensova (2006), according to her the brand value represents an asset for the enterprise and a representative example of its possession is a consequent increase in turnover, leadership within the pricing policy or gains from the sale of licensing rights. Author also considers the brand value important for the needs of the exact calculation in the case of purchase or sale of the enterprise, disposing of with a strong brand and also in the case of verification 
of reasonable amount of damages if there was a so-called brand piracy. In the classification of models dealing with the brand value, this approach can be included in the financially oriented. However, the author does not elaborate the prevenient method of quantification of the brand value given by the specifics of the Slovak environment.

Attention to the issue of the brand value was also partially paid as a part of the own research activities of the workplace submitting this factual intent (Salamovska, Todorovska 2016), but these researches were primarily focused on the assessment of the applicability of traditional marketing models to specific conditions of brand management, which similarly as in the previous case don't resulted in a creation of a model suited to the specifics of Slovak Republic. In comparison with the traditional school of brand management that are evolving in the USA (Wharton School University of Pennsylvania, Vincent C. Ross Institute of Accounting Research New York University, Kellogg School of Management at North western University), Singapore (Nanyang Polytechnic), Spain (Spanish business school EOI), France (HEC School of Business), Germany (Technological University of Dresden), Sweden (Chalmers University of Technology) or in the Czech Republic (University of Prague), the current state of the Slovak Republic is disappointing.

The resulting situation causes that building and managing the brand value in the conditions of the Slovak Republic is realized by the implementation of models inconvenient to specificities, consideration of which is a fundamental premise for achieving an optimal state. Those, in the context of the need to take into account the national environment, correlate not only with the subjective perception of resources of the brand value that influences the consumer's behaviour, but also with the uniqueness of Slovak accounting and reporting system.

The need for modifications of the existing methods of brand valuation for their full utilization in the context of building and managing the brand value in terms of specific markets is pointed out by Cizinska and Krabec (2014). According to them, the evaluation of intangible assets of companies, whose shares are not listed, and which operate on emerging markets, is a problem because of lack of empirical data or because of their inferior quality. Authors put in doubt the reliability and validity of data obtained by the use of models for quantification of the brand value obtained from foreign sources and propose their own model - the so-called VIM model (Verifiable Interdependent Model), consists of the quantification of the brand value as a specific component of an intangible asset of the company on the basis of determination of the brand value as a whole.

\section{Methodology}

As mentioned above, there are a lot of significantly different approaches to brand value measurement that invokes the need of the developed managerial skills to implement them appropriately in the way that brand value will be managed effectively.

Because of the range of the paper, we focused only on the comparison of financial methods of brand value evaluation. The reason for such a limitation is that the financial methods are the pillar of the preferred cross-sectional approach. To fulfil the aim of this paper, we decided to provide the case study of a selected Slovak company. This company operates at the insurance sector and provides its services at the international level. It has been established in 1996, which indicates its successful market performance and valuable brand existence. We decided to choose this company to verify the applicability of methods generally recommended by theorists in specific sectoral and national conditions. Slovak republic is representative of the future implications of findings in the former post socialistic countries of central and eastern Europe. The reason is similarity of market characteristics of these countries - lack of continual evolution of brand management practice (due to the centrally planned economy), specifics in accounting practice and financial statements and their difference from US GAPP standards which is the commonly used base for financial brand value determination, lack of scientific literature and theory adequate to the specific socio-psychographic regional profile in scope of brand value sources perception, specifics in perception of the essence of brand value (quality in former 'eastern' countries on the one hand and the image of traditionally 'western' countries on the other hand). 
We applied selected metrics of brand value quantification (an essential criterion for its selection has been set as the access to the data in the scope of Slovak accounting standards and the practice of Slovak companies) and we critically compared the obtained results.

Based on the application of selected criteria (theoretic concepts and recommendations, access to the data, common practice of Slovak companies and character of the method), we applied these methods of brand value measurement: royalty savings and brand value added (BVA ${ }^{\mathrm{TM}}$ method). The advantages and disadvantages of these models are shown in Table 1 and Table 2.

Table 1. Advantages and disadvantages of royalty savings method (Source: author's compilation)

\begin{tabular}{|l|l|}
\hline \multicolumn{1}{|c|}{ Advantages } & \multicolumn{1}{|c|}{ Disadvantages } \\
\hline $\begin{array}{l}\text { It calculates the brand value by reference to the } \\
\text { documented third-party transactions }\end{array}$ & Very few brands are actually comparable \\
\hline $\begin{array}{l}\text { The value yielded by the application of this method is } \\
\text { industry-specific }\end{array}$ & $\begin{array}{l}\text { The royalty rate generally includes more than just } \\
\text { one brand and the problem lies in determining what } \\
\text { part of royalty derives exclusively from the brand and } \\
\text { what part from the set of obligations outlined in the } \\
\text { contract }\end{array}$ \\
\hline $\begin{array}{l}\text { It is also theoretically appealing as it removes the } \\
\text { intrinsic difficulty of estimating the differential } \\
\text { profitability attributable to the brand }\end{array}$ & $\begin{array}{l}\text { The royalties estimated through this method may } \\
\text { represent only a portion of a profit attributable to the } \\
\text { brand }\end{array}$ \\
\hline $\begin{array}{l}\text { It has been accepted by many fiscal authorities as a } \\
\text { suitable model }\end{array}$ & $\begin{array}{l}\text { It provides a 'floor' or a 'minimum value' for the } \\
\text { brand that does not consider the 'upside value' of } \\
\text { having a total control of the brand }\end{array}$ \\
\hline
\end{tabular}

Table 2. Advantages and disadvantages of $\mathrm{BVA}^{\mathrm{TM}}$ method (Source: author's compilation)

\begin{tabular}{|l|l|}
\hline \multicolumn{1}{|c|}{ Advantages } & \multicolumn{1}{c|}{ Disadvantages } \\
\hline $\begin{array}{l}\text { It provides an explicit distinction between the added } \\
\text { value a brand offers to customers/consumers, and the } \\
\text { added value offered to the brand owner, and lists a } \\
\text { market share as a brand equity component }\end{array}$ & Originally developed as an index that applied to EVA \\
\hline $\begin{array}{l}\text { Useful for understanding the demand drivers in a } \\
\text { particular sector in order to ultimately enhance } \\
\text { decision-making and strategic analysis }\end{array}$ & It is not suitable for the calculation of fair value \\
\hline $\begin{array}{l}\text { It can be applied to different 'income or profit bases' } \\
\text { because there is no existing theoretical or empirical } \\
\text { argument that justifies the relationship between } \\
\text { BVA® and EVA }\end{array}$ & $\begin{array}{l}\text { The numeric results yielded by this approach are } \\
\text { generally dispensed with and greater emphasis is put } \\
\text { on demand driver analysis itself }\end{array}$ \\
\hline
\end{tabular}

Royalty savings model determines the brand value with respect to the royalty rate that would be payable for the use of the brand, if it had to be licensed from a third party.

The royalty rates are set on the basis of typical royalty rates charged by competitors who own similar brands operating in the same sector. Brand value according to this model is calculated as follows (Eq. 1):

$$
B V=\frac{S \times R R \times F O \times P A}{C R}
$$


where

$B V$ is the annual value of intangible assets (brand value);

$S$ is the annual sales;

$R R$ is the royalty rate;

$F O$ is the obsolescence factor;

$C R$ is the capitalization rate;

$P A$ is the proportion of intangible assets to production.

BVA $^{\mathrm{TM}}$ method uses Economic Value Added as the basis for calculation and is supplemented by BVA INDEX that enables the EVA-based calculation of earnings attributable to brand. BVA INDEX is produced through demand driver analysis consisting of ten objectively verifiable key brand performance indicators - time on the market, distribution, market share, market position, rate of sales growth, price additional charge, price elasticity, marketing costs, awareness of advertising and brand awareness. Each indicator is rated by a value from 0 to 10 and the final sum is divided by 100 . The value of a brand is then calculated according to Eq. 2:

$$
B V=\frac{E V A \times B V A I N D E X-T A X}{(1+d r)^{t}}
$$

where
$B V$ is the brand value;
$E V A$ is the economic value added;
$B V A I N D E X$ is the calculated index BVA;
$T A X$ is the amount of tax;
$d r$ is the discount rate;
$t$ is the individual time period.

Selected models are based on the discounted future income, so the main task was to set the appropriate discount rate, which can be calculated through various methods. The calculation of discount rate in this study was done using the basic interest rate, coefficient Beta and risk premium. Subsequently, the calculated discount factors were substituted to the formulas of brand value calculation in scope of three selected methods. The informational basis for such a calculation were financial statements of company.

The basic interest rate is determined by the Slovak national bank and its main role lies in the refinancing operations. Central bank provides information about the basic interest rate on its website. In essence, it is the rate at which the National Bank provides funds to commercial banks. From 9 December 2016, the base rate of the ECB's interest rate is $0.05 \%$, the main refinancing operation rate.

The calculation of the discount rate is also possible by using the beta coefficient, which expresses the risk of the sector in which the company operates. Average industry-specific beta coefficients are available in professional literature and on the websites dealing with the issue.

The current beta value for the Insurance Industry - Insurance is $2.26 \%$. The total discount rate is then calculated as the sum of the risk-free rate and beta coefficient. The risk-free interest rate was set as the average of the risk-free interest rates - the yield on government bonds at $4.2 \%$. So, the discount rate calculated by using the beta coefficient is $6.46 \%$. 
The use of the risk premium serves to calculate the discount rate, with the resulting discount rate being achieved, similar to the previous methods, to the sum of the risk-free rate and the risk margins. Benchmarking of individual BrandBetaTMs takes place on a scale of 1 to 10 , the values being determined on the basis of internal business information, annual reports, expert estimates and management consultations (see Table 3).

Table 3. Brand value calculated by method of royalty savings (Source: author's compilation)

\begin{tabular}{|c|c|}
\hline Attribute & Score (1-10) \\
\hline Existence on the market & 9 \\
\hline Distribution & 8 \\
\hline Market share & 6 \\
\hline Market position & 7 \\
\hline Sales growth & 7 \\
\hline Price premium & 5 \\
\hline Price elasticity & 6 \\
\hline Marketing expenditures & 7 \\
\hline Advertising awareness & 5 \\
\hline Brand awareness & 69 \\
\hline Total & 9 \\
\hline
\end{tabular}

When substituting to Equation 2, we can state that the discount rate calculated by the risk premium method is $9.408 \%$.

\section{Results}

Based on the mutual combination of royalty savings method and BVA ${ }^{\mathrm{TM}}$ method with discount rates calculated with the usage of basic interest rate, coefficient Beta and risk premium, the final values of brands of selected company were detected.

When applying royalty savings, the highest brand value was achieved using a discount rate derived from the Slovak national bank's basic interest rate. On the other hand, the lowest brand value was calculated at a discount rate derived from the risk premium (Table 4).

Table 4. Brand value calculated by method of royalty savings (Source: author's compilation)

\begin{tabular}{|c|c|c|c|c|c|c|c|c|c|c|}
\hline$\stackrel{\grave{\nexists}}{\grave{\nu}}$ & $\frac{\tilde{\omega}}{\tilde{E}}$ & 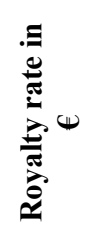 & 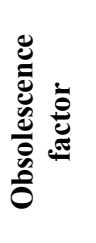 & 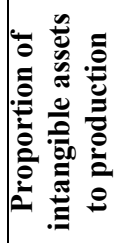 & 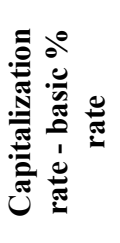 & 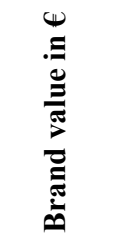 & 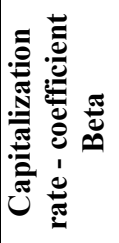 & 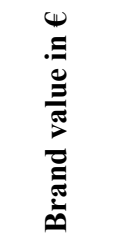 & 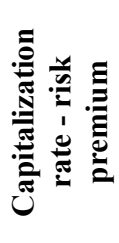 & 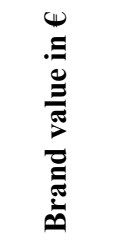 \\
\hline 2016 & 432420 & 4324,2 & 1,02 & 1 & 1,0005 & 0 & 1,0646 & 0 & 1,0941 & 0 \\
\hline 2017 & 449716,8 & 4497,2 & 1,034 & 1 & 1,0005 & 4647,75 & 1,0646 & 4367,91 & 1,0941 & 4250,21 \\
\hline 2018 & 467705,5 & 4677,1 & 1,039 & 1 & 1,0010 & 4854,61 & 1,0890 & 4462,31 & 1,1080 & 4385,79 \\
\hline 2019 & 486413,7 & 4864,1 & 1,040 & 1 & 1,0014 & 5053,57 & 1,0950 & 4621,60 & 1,1150 & 4538,70 \\
\hline 2020 & 505870,2 & 5058,7 & 1,061 & 1 & 1,0017 & 5359,18 & 1,1080 & 4845,03 & 1,1290 & 4754,91 \\
\hline
\end{tabular}




\begin{tabular}{|l|c|c|c|c|c|c|c|c|c|c|}
\hline 2021 & 526105 & 5261,1 & 1,082 & 1 & 1,0021 & 5682,63 & 1,1170 & 5098,09 & 1,3400 & 4249,67 \\
\hline 2022 & 547149,2 & 5471,5 & 1,094 & 1 & 1,0026 & 5967,56 & 1,1340 & 5276,08 & 1,3900 & 4304,37 \\
\hline
\end{tabular}

When applying the $\mathrm{BVA}^{\mathrm{TM}}$ method, the brand value reached the highest value using the discount rate derived from the basic interest rate, while the lowest brand value was reached using the risk premium to calculate the discount rate. See Table 5 and Table 6.

Table 5 summarizes the basic data needed to calculate the brand value using BVATM (net turnover, operating profit, used tangible assets, rate on capital, EVA, BVA index, tax value and BVA after taxes).

Table 5. Brand value calculated by method of BVA ${ }^{\text {TM }}$ I. (Source: author's compilation)

\begin{tabular}{|c|c|c|c|c|c|c|c|c|}
\hline$\stackrel{\bar{\Xi}}{\bar{J}}$ & 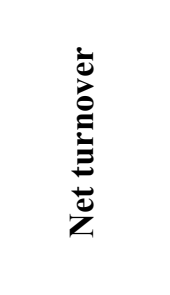 & 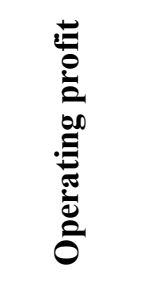 & 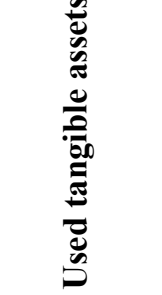 & 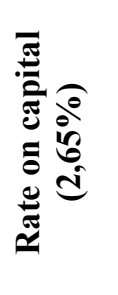 & 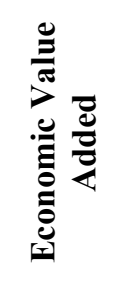 & 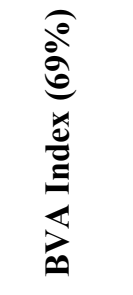 & 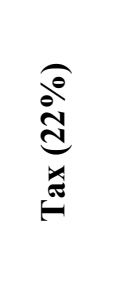 & \\
\hline 2016 & 432420,00 & 3651,28 & 24620,00 & 652,43 & 2998,85 & 2069,21 & 455,23 & 1613,98 \\
\hline 2017 & 449716,80 & 3797,33 & 25358,60 & 672,00 & 3125,33 & 2156,48 & 474,43 & 1682,05 \\
\hline 2018 & 467705,47 & 3949,23 & 26119,36 & 692,16 & 3257,07 & 2247,38 & 494,42 & 1752,95 \\
\hline 2019 & 486413,69 & 4107,20 & 26902,94 & 712,93 & 3394,27 & 2342,05 & 515,25 & 1826,80 \\
\hline 2020 & 505870,24 & 4271,49 & 27710,03 & 734,32 & 3537,17 & 2440,65 & 536,94 & 1903,70 \\
\hline 2021 & 526105,05 & 4442,34 & 28541,33 & 756,35 & 3686,00 & 2543,34 & 559,53 & 1983,80 \\
\hline 2022 & 547149,25 & 4620,04 & 29397,57 & 779,04 & 3841,00 & 2650,29 & 583,06 & 2067,23 \\
\hline
\end{tabular}

Table 6 contains the calculated values of brand according to the used method of discount rate calculation.

Table 6. Brand value calculated by method of BVA ${ }^{\text {TM }}$ II (Source: author's compilation)

\begin{tabular}{|c|c|c|c|c|c|c|}
\hline$\stackrel{\bar{\varpi}}{\bar{\nu}}$ & 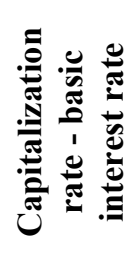 & 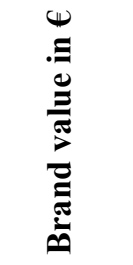 & 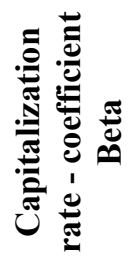 & 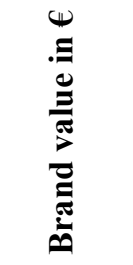 & 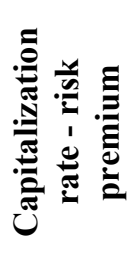 & 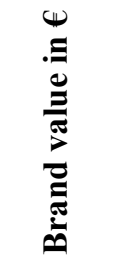 \\
\hline 2016 & 1,0000 & 1613,98 & 1,0000 & 1613,98 & 1,00000 & 1613,98 \\
\hline 2017 & 1,0005 & 1681,21 & 1,0646 & 1579,99 & 1,09408 & 1537,41 \\
\hline 2018 & 1,0010 & 1749,45 & 1,0890 & 1478,14 & 1,1080 & 1427,88 \\
\hline 2019 & 1,0014 & 1819,14 & 1,0950 & 1391,39 & 1,1150 & 1317,85 \\
\hline 2020 & 1,0017 & 1890,81 & 1,1080 & 1263,11 & 1,1290 & 1171,72 \\
\hline
\end{tabular}




\begin{tabular}{|c|c|c|c|c|c|c|}
\hline 2021 & 1,0021 & 1963,11 & 1,1170 & 1140,86 & 1,3400 & 459,17 \\
\hline 2022 & 1,0026 & 2035,27 & 1,1340 & 972,10 & 1,3900 & 286,62 \\
\hline Brand value to 2017 & & $\mathbf{1 2 ~ 7 5 2 , 9 8}$ & & $\mathbf{8 ~ 6 5 5 , 5 1}$ & & $\mathbf{9 4 3 9 , 5 6}$ \\
\hline Annuity & & $\mathbf{1 2 ~ 7 4 6 , 6 1}$ & & $\mathbf{7 7 9 0 , 7 3}$ & & $\mathbf{8 8 6 6 , 7 7}$ \\
\hline Total brand value & & $\mathbf{2 5 ~ 4 9 9 , 5 9}$ & & $\mathbf{1 6 ~ 4 4 6 , 2 4}$ & & $\mathbf{1 8 ~ 3 0 6 , 3 3}$ \\
\hline
\end{tabular}

According to the above written, it is obvious that the highest brand value of $€ 31,565.30$ was achieved by applying the royalty savings method using a discount rate derived from the base interest rate. Vice versa, the lowest brand value of $€ 14,957.28$ was achieved by applying the BVA method using a discount rate derived from the risk premium (Table 7).

Table 7. Comparison of brand value calculated by royalty savings and BVA $^{\mathrm{TM}}$ (Source: author's compilation)

\begin{tabular}{|c|l|c|}
\hline Rank & Used method of brand value calculation & Brand value in $\boldsymbol{\epsilon}$ \\
\hline 1 & Royalty savings - basic interest rate & 31565.30 \\
\hline 2 & Royalty savings- BETA coefficient & 28671.01 \\
\hline 3 & Royalty savings - risk premium & 26483.66 \\
\hline 4 & BVA method - basic interest rate & 25499.59 \\
\hline 5 & BVA method - BETA coefficient & 16446.24 \\
\hline 6 & BVA method - risk premium & 14957.28 \\
\hline
\end{tabular}

In spite of the highest achievable brand values, using the above discount rate, it is more convenient to use other variants such as a beta coefficient or a risk premium. The central bank's key interest rate does not take into account inflation, and it also does not take market risk into account. Average brand value obtained from the calculated six variants of the brand value is $€ 24,247.20$. The spread of the calculated values is significantly different - the difference between extremes of the calculated values is $€ 16,608.2$, which indicates a need of the brand value metrics adaptation to the specifics of its environment.

These findings are applicable in theory and practice of brands that meet these framework conditions:

- long term effective market performance,

- international range of business activities,

- core business operated in market of central or eastern Europe.

\section{Conclusions}

Although brand value management is a relatively new management discipline, an increasing number of businesses pay attention to this intangible property of the enterprise. The value of the brand significantly influences the success of the business on the market and often reaches values higher than the value of the tangible assets of the company. Increased interest in the value of the brand of the company is reflected in the use of different methods of calculating brand value, each method having its advantages and disadvantages. But currently, there is no method accepting the specific conditions 
of the Slovak market. Because of this, we realized that a case study focused on the assessment of the usability of selected brand value metrics - royalty savings and brand value added method. We found that there are significant divergences between the obtained results due to the use of the method of discount rate calculation. The highest brand value is calculated when the method of royalty savings based on the basic interest rate is applied, while the lowest brand value is calculated when the method of BVA method based on the risk premium is applied. Summarizing the findings, we can state that in specific conditions of selected insurance company operating on Slovak market, the BVA method based on the basic interest rate is optimal (due to its approximation to the calculated average brand value); although, the method of royalty savings is the most recommended. The provided case study was the pilot study for the confirmation of research assumptions, which should be verified by a more in-depth study realized in specific national and sectoral conditions.

\section{Acknowledgements}

Support for this work was provided by the Slovak Research and Development Agency through the Grant NO. APVV-15-0505 titled 'Integrated model of management support for building and managing the brand value in the specific conditions of the Slovak Republic'.

\section{References}

Aaker, D. A. (2003). Brand building. Brno: Computer Press.

Beccaceci, F., Borgonovo, E., \& Reggiani, F. (2006). Risk Analysis in Brand Valuation. SSRN eLibrary. [Accessed 20.04.2017]. Available from Internet: http://ssrn.com/abstract=931023.

Beleska-Spasova, E., Loykulnanta, S., \& Nguyen, Q.T.K. (2016). Firm-specific, national and regional competitive advantages: The case of emerging market MNEs-Thailand. Asian Business \& Management, 15(4), 264-291.

Cizinska, R., \& Krabec, T. (2014). Destroying and Creating Equity Value Through Brand Management: Positive and Negative Brand Impact Assessment by Using the VIM Modelling Approach. Journal of Contemporary Management Issues, 19 (1), 213-230.

Damodaran, A. (1996). Investment valuation: tools and techniques for determining the value of any asset. New York: John Wiley \& Sons.

Feltham, G. A., \& Ohlson, J. A. (1999). Residual earnings valuation with risk and stochastic interest rates. Accounting Review, 74 (2), 165-183.

Fischer, M. (2007). Valuing brand assets: a cost-effective and easy-to-implement measurement approach. Working Paper Series, Marketing Science Institute (MSI), 25-50.

Heine, K., \& Gutsatz, M. (2015). Luxury brand building in China: Eight case studies and eight lessons learned, Journal of Brand Management, 22(3), 229-245.

Herp, T. (1982). Der Markenwert von Marken des Gebrauchs-gutersektors. Frankfurt am Main: Peter Lang.

Chailan, C., \& Ille, F. (2015). Branding from emerging countries: how to compete internationally? Critical Perspectives on International Business, 11 (1), 54-71.

Kapferer, J. N. (2012). The new strategic brand management - Advanced insights \&strategic thinking. London: Kogan Page.

Keller, K. L. (2007). Strategic brand management. Praha: Grada Publishing.

Krizanova, A., Masarova, G., \& Stefanikova, L. (2014). The importance of brand management in the automotive industry in the Slovak market. ICMIBI 2014: Management innovation and business - 2nd international conference on Management innovation and business. Conference proceedings, 23-28.

Lev, B. (1999). Seeing is believing: A better approach to estimating knowledge capital. CFO Asia Magazine, 15 (2), 29-37.

Lizbetinova, L., \& Weberova, D. (2016). Managing attitudes of consumers towards brands and quality. IBIMA 2016: 27th International Business Information Management Association Conference - Innovation Management 
and Education Excellence Vision 2020: From Regional Development Sustainability to Global Economic Growth. Conference proceedings, 2147-2156.

Moisescu, O. I. (2007). A conceptual analysis of brand evaluation. Munich: MPRA Paper No. 32017, 93-98.

Raboy, D., \& Wiggins, S. (1997). Intangible capital, hedonic pricing and international transfer prices. Public Finance Quarterly, 25 (4), 347-365.

Riesenbeck, H. (2000). Nur Power-Marken überleben. Akzente, (16), 10-15.

Salamovska, S.M., \& Todorovska, M. (2016). Brand Valuation and Marketing Assets Assessment - Theoretical Background vs. Contemporary Managerial Issues. Strategic Management, 21 (4), 37-44.

Salinas, G. (2009). The international brand valuation manual - A complete overview and analysis of brand valuation techniques, methodologies and applications. Chichester: John Wiley \& Sons.

Sattler, H., Högl, S., \& Hupp, O. (2002). Evaluation of the financial value of brands. Research papers on marketing and retailing. Hamburg: Hamburg University Press.

Sydoruk, S.V. (2016). Specifics of forming brand of hotel services in region. Scientific Bulletin of Polissia, (3), 117-123.

Starchon, P., Lizbetinova, L., \& Weberova, D. (2016). Clustering in relation to brand perception: An example based on Czech consumers. 28th International Business Information Management Association Conference Vision 2020: Innovation Management, Development Sustainability, and Competitive Economic Growth. Conference proceedings, 2271-2285.

Stensova, A. et al. (2006). Brand management - selected problems. Bratislava: Ekonom.

Vazquez, R., del Rio, A. B., \& Iglesias, V. (2002). Consumer-based brand equity: Development and validation of a measurement instrument. Journal of Marketing Management, 18 (1-2), 27-48.

Veloutsou, C., \& Guzman, F. (2017). The evolution of brand management thinking over the last 25 years as recorded in the Journal of Product and Brand Management. Journal of Product and Brand Management, 26 (1), $2-12$.

Weberova, D., \& Lizbetinova, L. (2016). Consumer attitudes towards Brands in relation to price. IBIMA 2016: 27th International Business Information Management Association Conference - Innovation Management and Education Excellence Vision 2020: From Regional Development Sustainability to Global Economic Growth. Conference proceedings, 1850-1859.

Zimmermann, R., Klein-Bölting, U., Sander, B., \& Murad-Aga, T. (2001). Brand equity review, brand equity excellence. Düsseldorf: BBDO Group Germany. 